\title{
PERBANDINGAN TERAPI AIR PUTIH DENGAN KOMPRES HANGAT TERHADAP PENURUNAN SKALA NYERI HAID (DISMENOREA PRIMER) PADA REMAJA
}

\author{
Nora Isa Tri Novadela*, Rahmi Aziza Hardini*, Mugiati* \\ *Jurusan Kebidanan Poltekkes Tanjungkarang \\ E-mail: Noraisatrinovadela@yahoo.co.id
}

\begin{abstract}
Dismenorea merupakan nyeri spasmodik pada perut bagian bawah pada saat menstruasi dan banyak dialami oleh remaja putri di Bandar Lampung. Beberapa penanganan dismenorea non farmakologi diantaranya yaitu dengan terapi air putih dan kompres hangat. Jenis penelitian analitik dengan rancangan pra eksperimen (two group pretest-posttest). Populasi dalam penelitian ini adalah Siswi Madrasah Aliyah pada salah satu Pesantren di Kota Bandar Lampung dengan sampel sebanyak 32 orang. Teknik sampling yang digunakan adalah purposive sampling. Sumber data yang digunakan adalah data primer yang diperoleh secara langsung dari responden, alat pengumpulan data berupa kuesioner, analisis bivariat menggunakan uji-T dependen dan uji-T independen. Hasil penelitian didapatkan dari 32 responden ratarata skala nyeri yang mereka rasakan sebelum diberikan terapi air putih adalah 5,50 dan rata-rata skala nyeri yang dirasakan setelah diberikan terapi air putih adalah 3,00. Rata-rata skala nyeri yang mereka rasakan sebelum diberikan kompres air hangat adalah 4,69 dan rata-rata skala nyeri yang dirasakan setelah diberikan kompres air hangat adalah 2,06. Hasil statistik dari uji-T sampel independent didapatkan selisih rata-rata skala nyeri sebelum dan setelah diberikan terapi air putih 2,50 dan selisih rata-rata skala nyeri sebelum dan setelah diberikan kompres air hangat 2,625. Kesimpulan dari penelitian ini adalah kompres hangat lebih efektif untuk menurunkan skala nyeri haid (dismenorea primer) pada siswi di salah satu Pondok Pesantren di Kota Bandar Lampung. Diharapkan UKS yang berada di Ponpes dapat memberikan penyuluhan mengenai penanganan dismenorea khususnya komnpres hangat pada setiap bulan.
\end{abstract}

Kata kunci: dismenorhea, kompres hangat, terapi air putih

\section{LATAR BELAKANG}

Dismenorea merupakan gangguan menstruasi yang sering dialami oleh remaja putri. Dismenorea ditandai dengan nyeri perut bagian bawah dan dapat disertai dengan gejala gejala lainnya. Sebagian besar nyeri haid terjadi saat usia remaja dan dapat menimbulkan dampak konflik emosional, ketegangan dan kegelisahan. Akibat dismenore mereka bahkan tidak dapat pergi kesekolah, aktivitas belajar dalam pembelajaran terganggu, konsentrasi menjadi menurun bahkan tidak ada sehingga materi yang diberikan selama pembelajaran yang berlangsug tidak bisa ditangkap oleh remaja yang sedang mengalami dismenorea (Made Lestari, 2013).

Menurut data dari WHO pada tahun 2012 didapatkan kejadian sebesar 1.769.425 jiwa (90\%) remaha mengalami dismenorhea dengan $10-15 \%$ mengalami dismenorhea berat. Persentase angka terjadinya dismenorhea pada remaja di Amerika Serikat sekitar $60 \%$ dan di Swedia sekitar $72 \%$. Sementara, di Indonesia sendiri angka kejadian dismenorhea sebesar 107.673 jiwa $(64,25 \%)$, yang terdiri dari 59.671 jiwa $(54,89 \%)$ mengalami dismenorhea primer dan 9.496 jiwa $(9,36 \%)$ mengalami dismenorhea sekunder. Menurut data dari Provinsi Lampung, angka kejadian nyeri saat menstruasi (dismenorea) sangat besar. Lebih dari $50 \%$ remaja di Lampung mengalami dismenorea. Menurut hasil survey Perkumpulan Keluarga Berencana Indonesia (PKBI) cabang Bandar Lampung pada tahun 2014, dismenorhea menempati urutan pertama keluhan yag sering dialami wanita, sebesar $65,3 \%$ selain siklus menstruasi yang tidak benar. Pravelensi dismenorhea lebih tinggi pada kelompok usia remaja 10-20 tahun sebebsar 71,4\% (Palupi, 2016), sedangkan menurut survei 
yang dilakukan terhadap jumlah remaja di Lampung pada tahun 2008 didapatkan sejumlah $58,2 \%$ remaja mengalami dismenorhea yang menyebabkan mereka terganggu aktifitasnya, seperti sulit beraktifitas, dan absen dari mata pelajaran (Utami, 2014).

$$
\text { Penyebab terjadinya nyeri }
$$
dismenorea dikarenakan adanya peningkatan hormon prostaglandin. Hormon ini mengakibatkan kontraksi uterus dan vasokonstriksi pembuluh darah. Aliran darah yang menuju ke uterus menurun sehingga uterus tidak mendapat suplai oksigen yang adekuat sehingga menyebabkan nyeri (Astrida Rakhma, 2013).

Secara umum penanganan nyeri dismenorea terbagi dalam dua kategori pendekatan farmakologis dan non farmakologis. Secara farmakologis nyeri dapat ditangani dengan terapi analgesik yang merupakan metoda paling umum digunakan untuk menghilangkan nyeri (Dwi Christina, 2016). Menurut penelitian yang dilakukan oleh Astrida Rakhma tahun 2013, upaya penangan dismenorea secara non farmakologi terdiri dari istirahat total atau tidur, teknik distraksi, kompres hangat, pengobatan herbal, posisi knee chest, teknik menarik nafas dalam, dan pemijatan., sedangkan menurut penelitian yang dilakukan Paulus Ama Suban tahun 2017, terdapat pengaruh terapi air putih yang bermakna terhadap penurunan dismenorhea primer pada remaja terapi air putih membantu menurunkan ketegangan uterus, merelaksasikan otot dan memperlancar peredaran darah.

Penggunaan dari kompres hangat dapat membuat sirkulasi darah lancar, vaskularisasi lancar dan terjadi vasodilatasi yang membuat relaksasi pada otot karenan otot mendapat nutrisi yang dibawa oleh darah sehingga kontraksi otot menurun (Eka, Rahmalia dkk, 2017). Menurut penelitian yang dilakukan oleh Paulus Ama Suban tahun 2017, terapi minum air putih bertujuan untuk membantu mencairkan darah beku (stolsel), sehingga aliran darah haid menjadi lancar (Muhammad, 2011). Pernyataan Amirta
(2007), bahwa satu-satunya alat pengangkut di dalam tubuh untuk mengumpulkan sampah-sampah sel dari seluruh bagian tubuh yang telah mati adalah dengan minum air putih. Di dalam air putih mengandung tujuh meneral alami yang sangat dibutuhkan oleh tubuh diantaranya fluorida, natrium, kalium, magnesium, kalsium, zinc, dan silika, dimana ada beberapa dari tujuh mineral tersebut yang berperan penting dalam menurunkan nyeri haid (dismenorhea), yakni magnesium dan kalsium.

\section{METODE}

Jenis penelitian eksperimen dengan rancangan pra eksperimen (two group pretest-posttest). Populasi dalam penelitian ini adalah siswi yang tinggal di salah satu Pondok Pesantren di Kota Bandar Lampung dengan jumlah sampel sebanyak 32 responden yang mengalami dismenorea selama 3 bulan berturut-turut. Teknik sampling purposive sampling, yaitu pengambilan sampel didasarkan pada suatu pertimbangan tertentu yang dibuat oleh peneliti. Data yang digunakan data primer yang diperoleh secara langsung dari responden, alat pengumpulan data berupa kuesioner. Analisis bivariat dengan menggunakan uji-T dependen dan uji-T independen.

\section{HASIL}

Tabel 1: Distribusi Frekuensi Lama Waktu untuk Penyembuhan Luka Jahitan Perineum

\begin{tabular}{ccccc}
\hline \multirow{2}{*}{$\begin{array}{c}\text { Waktu } \\
\text { (Hari) }\end{array}$} & \multicolumn{3}{c}{ Tidak } & \multicolumn{2}{c}{ Ya } \\
\cline { 2 - 5 } & $\mathrm{f}$ & $\%$ & $\mathrm{f}$ & $\%$ \\
\hline 1 & 0 & 0 & 0 & 0 \\
\hline 2 & 0 & 0 & 0 & 0 \\
\hline 3 & 0 & 0 & 0 & 0 \\
\hline 4 & 0 & 0 & 0 & 0 \\
\hline 5 & 0 & 0 & 2 & 12,5 \\
\hline 6 & 0 & 0 & 4 & 25 \\
\hline 7 & 2 & 12,5 & 6 & 37,5 \\
\hline$>7$ & 14 & 87,5 & 4 & 25 \\
\hline Total & 16 & 100 & 16 & 100 \\
\hline
\end{tabular}


Berdasarkan Tabel di atas lama penyembuhan luka perineum untuk masing-masing perlakuan berbeda. Untuk kelompok tidak mengonsumsi telur rebus responden sembuh lebih dari 7 hari lama waktu penyembuhan yaitu sekitar $87,5 \%$. Namun untuk jenis tindakan yang mengkonsumsi telur mayoritas responden sembuh pada hari ke 7 dengan $37,5 \%$ dengan banyak respobden yaitu 6 responden. Sedangan pada rentang waktu 1-6 hari responden belum terlihat penyembuhan luka untuk jenis tindakan yang tidak mengkonsumsi telur. Sedangkan untuk jenis tindakan mengkonsumsi telur pada hari ke5 ada sekitar $12,5 \%$ yaitu 2 responden yang mengalami penyembuhan luka dengan baik, 4 responden $25 \%$ sembuh hari ke 6 , dan yang sembuh lebih dari 7 hari sebanyak 4 responden $25 \%$.

Tabel 2: Analisis perbedaan rata-rata waktu penyembuhan luka pada kelompok intervensi dan kontrol

\begin{tabular}{lcccc}
\hline Kelompok & $\mathrm{n}$ & Mean & $\mathrm{SD}$ & p value \\
\hline Intervensi & 16 & 4,194 & 0,8752 & \multirow{2}{*}{0,000} \\
\hline Kontrol & 16 & 5,544 & 0,6282 & \\
\hline
\end{tabular}

Tabel di atas menunjukkan rata-rata (mean) waktu yang dibutuhkan ibu nifas yang mengonsumsi telur rebus rata-rata 4,194 hari, sedangkan waktu yang dibutuhkan ibu nifas untuk penyembuhan luka perineum yang tidak mengonsumsi telur rebus adalah 5,544 hari. Hasil p-value yang diperoleh dalam uji analasis t-tes independen di dapatkan $p$-value $=0,000$ yang berarti ada pengaruh konsumsi telur rebus terhadap penyembuhan luka perineum pada ibu nifas 1-7 hari.

\section{PEMBAHASAN}

\section{Nyeri Sebelum Diberikan Terapi Air Putih}

Berdasarkan hasil penelitian terhadap 16 responden tentang perbandingan terapi air putih dan kompres air hangat terhadap penurunan skala nyeri haid (dismenorea primer) pada siswi di Pondok Pesantren
Al-Hikmah Way Halim Bandar Lampung diperoleh rata-rata skala nyeri haid sebelum diberikan terapi air putih 5,50 dengan standar deviasi 1,713.

Hal tersebut sejalan dengan teori yang disampaikan oleh Anurugo \& Wulandari (2011), nyeri yang dirasakan pada saat menstruasi muncul akibat kontraksi disritmik miometrium yang menampilkan satu gejala atau lebih, mulai dari nyeri yang ringan sampai berat diperut bagian bawah, bokong, dan nyeri spasmodik disisi medial paha.

Menurut peneliti kesesuaian oleh salah satu faktor yaitu, selama menstruasi rahim berkontraksi untuk meluruhkan lapisannya, yang keluar sebagai darah haid. Hal tersebut membuat pengeluaran cairan lebih banyak dan memungkinan terjadinya dehidrasi sel yang lebih besar, salah satunya pada sel-sel endometrium. Cairan yang hilang dari tubuh terutama pada otot dapat menyebabkan ketegangan sehingga mengganggu proses kontraksi otot rahim. Ketika otot rahim berkontraksi, pembuluh darah yang melapisi rahim menjadi tertekan, apabila pembuluh darah tersebut terlalu lama mengalami penekanan akan mengakibatkan putusnya suplai darah serta oksigen ke dalam rahim. Tanpa oksigen yang memadai, jaringan di dalam rahim melepaskan hormon prostaglandin secara berlebihan yang memicu terjadinya rasa nyeri saat haid. Prostaglandin membuat otot rahim berkontraksi lebih kuat dan rasa nyeri menjadi semakin berat. Upaya mencegah terjadinya dehidrasi pada sel yang menyebabkan nyeri haid (dismenorhea) maka perlu dilakukan terapi air putih dengan baik dan teratur agar bisa memberikan efek penurunan intensitas nyeri (dismenorhea) secara nyata. Diharapkan dengan mengkonsumsi air secara teratur maka tidak akan terjadi dehidrasi sel terutama pada sel-sel endometrium yang dapat menyebabkan ketegangan pada otot sehingga mengganggu proses kontraksi otot rahim.

Oleh karena itu, bagi responden yang mengalami dismenorea primer sebaiknya teratur mengonsumsi air putih terutama saat haid. Dengan mengonsumsi minimal 8 
gelas/hari diharapkan hal tersebut dapat mencegah terjadinya dehidrasi sel dan terjadinya dismenorea.

\section{Nyeri Setelah Diberikan Terapi Air Putih}

Berdasarkan hasil penelitian terhadap 16 responden tentang perbandingan terapi air putih dan kompres air hangat terhadap penurunan skala nyeri haid (dismenorea primer) pada siswi di Pondok Pesantren Al-Hikmah Way Halim Bandar Lampung diperoleh rata-rata skala nyeri haid setelah diberikan terapi air putih mengalami penurunan menjadi 3,00 dengan standar deviasi 1,713 .

Hasil penelitian ini didukung oleh pendapat Muhammad (2011) yang menyatakan bahwa terapi air putih dapat mengatasi berbagai masalah kesehatan termasuk dismenorhea. Terapi air putih bertujuan untuk menjaga kesehatan dan keutuhan setiap sel dalam tubuh; menjaga tingkat cair aliran darah agar lebih mudah mengalir/lancar termasuk membantu mencairkan stolsel; melumasi dan melindungi persendian; dapat melarutkan dan membawa nutrisi, oksigen, dan hormone ke seluruh sel tubuh; melarutkan dan mengeluarkan zat-zat sampah sisa metabolisme dari dalam tubuh dan juga elektrolit yang berlebihan sebagai katalisator dalam tubuh; dapat menghasilkan tenaga; menstabilkan suhu tubuh; dan meredam benturan bagi organ vital di dalam tubuh. Hal serupa dikemukakan oleh Taber (2005) cara yang dapat dilakukan untuk mengatasi dismenorhea salah satunya adalah dengan perbanyak minum air putih. Pendapat ini didukung juga oleh Batmanghelidj (2007) yang menyatakan minum air putih dapat mengurangi nyeri menstruasi, air dapat mengencerkan darah, mencegah terjadinya dehidrasi pada sel dan mencegah penggumpalan darah ketika beredar ke seluruh tubuh, serta sumber utama energy bagi tubuh.

Menurut peneliti kesesuaian tersebut disebabkan oleh salah satu faktor yaitu, di dalam air putih mengandung tujuh meneral alami yang sangat dibutuhkan oleh tubuh diantaranya fluorida, natrium, kalium, magnesium, kalsium, zinc, dan silika. Menurut Dean (2010) magnesium berguna untuk merelaksasikan otot dan dapat memberikan rasa rileks yang dapat mengendalikan suasana hati yang murung (Hill, 2002). Selain itu magnesium juga berfungsi untuk memperbesar pembuluh darah sehingga mencegah terjadinya ketegangan otot dan dinding pembuluh darah. Oleh sebab itu megnesium berfungsi untuk mengurangi rasa sakit saat mentruasi atau dismenorhea primer (Sinaga, 2011). Menurut Karina Nurin R dan Anzhor Adhi $S$ (2017), saat menstruasi rahim sedang mengeluarkan darah kotor yang melekat di dinding rahim. Pelepasan sel darah kotor dari dinding rahim tersebut diduga yang menjadi penyebab timbulnya kram atau nyeri saat haid. Untuk menghindari semua itu harus mengonsumsi air. Terapi air putih bisa memudahkan darah kotor terlepas sempurna tanpa sisa di dinding rahim. Terapi air putih juga memudahkan kerja rahim untuk melepaskan sel darah kotor tersebut. Semakin mudah rahim untuk melepaskan darah kotor, semakin ringan pula nyeri yang akan dirasakan.

Oleh karena itu, responden diharapkan dapat rutin melakukan terapi air putih pada 3 hari sebelum menstruasi hingga hari kedua menstruasi. Dengan melakukan terapi air putih diharapkan terjadi penurunan nyeri yang dirasakan responden pada saat menstruasi.

\section{Nyeri Sebelum Diberikan Kompres Hangat}

Berdasarkan hasil penelitian terhadap 16 responden tentang perbandingan terapi air putih dan kompres air hangat terhadap penurunan skala nyeri haid (dismenorea primer) pada siswi di Pondok Pesantren Al-Hikmah Way Halim Bandar Lampung diperoleh rata-rata skala nyeri haid sebelum diberikan kompres air hangat yaitu 4,69 dengan standar deviasi 1,702.

Hal tersebut sejalan dengan teori yang disampaikan oleh Anurugo \& Wulandari (2011), nyeri yang dirasakan pada saat menstruasi muncul akibat kontraksi disritmik miometrium yang 
menampilkan satu gejala atau lebih, mulai dari nyeri yang ringan sampai berat diperut bagian bawah, bokong, dan nyeri spasmodik disisi medial paha.

Menurut peneliti kesesuaian disebabkan oleh salah satu faktor yaitu, selama menstruasi sel-sel endometrium yang terkelupas melepaskan prostaglandin (kelompok persenyawaan mirip hormon kuat yang terdiri dari asam lemak esensial. Prostaglandin merangsang otot uterus (rahim) dan memengaruhi pembuluh darah; biasa digunakan untuk menginduksi aborsi atau keahiran) yang menyebabkan iskemia uterus (penurunan suplai darah ke rahim) melalui kontraksi myometrium (otot dinding rahim) dan vasoconstriction (penyempitan pembuluh darah).

Oleh karena itu, bagi responden yang mengalami dismenorea primer sebaiknya memahami berbagai managemen non farmakologis untuk pengurangan rasa nyeri terutama kompres air hangat. Penggunaan kompres hangat diharapkan dapat meningkatkan relaksasi otot-otot dan mengurangi nyeri akibat spasme atau kekakuan serta memberikan rasa hangat lokal. Kompres hangat dapat menyebabkan pelepasan endorfin tubuh sehingga memblok transmisi stimulasi nyeri. Dengan begitu nyeri dismenorea dapat dikurangi sehingga aktivitas sehari-hari tidak terganggu.

\section{Nyeri Setelah Diberikan Kompres Hangat}

Berdasarkan hasil penelitian terhadap 16 responden tentang perbandingan terapi air putih dan kompres air hangat terhadap penurunan skala nyeri haid (dismenorea primer) pada siswi di Pondok Pesantren Al-Hikmah Way Halim Bandar Lampung diperoleh rata-rata skala nyeri haid setelah diberikan kompres air hangat mengalami penurunan menjadi 2,06 dengan standar deviasi 0,929.

Hasil penelitian ini didukung oleh pendapat Bazdiad (2008), kompres hangat bertujuan agar meningkatkan sirkulasi aliran darah ke bagian yang nyeri, menurunkan ketegangan otot dimana dapat meningkatkan relaksasi otot dan mengurangi nyeri akibat dari spasma atau kekakuan, dan juga memberikan rasa nyaman. Kompres hangat dengan menggunakan buli-buli panas yang mana secara konduksi dimana terjadi pemindahan panas dari buli-buli ke dalam tubuh sehingga akan menyebabkan pelebaran pembuluh darah sirkulasi menjadi lancar dan akan menjadi ketegangan otot, sesudah otot miometrium rilek, rasa nyeri yang dirasakan berangsurangsur berkurang bahkan hilang (Merdianita, 2013).

Menurut peniliti, kesesuaian tersebut disebabkan oleh salah satu faktor yaitu saat satu hari menjelang ovulasi hormon estrogen akan turun, dan hormon progesteron akan meningkat. Teori tersebut berhubungan dengan pengaruh kompres hangat terhadap dismenorea primer, karena mekanisme terjadinya penurunan nyeri akibat dilakukan kompres hangat karena panas menyebabkan vasodilatasi. Selain itu ketika kompres diberikan juga akan merangsang serat saraf yang menutup gerbang karena adanya sensasi hangat sehingga transmisi implus nyeri ke medula spinalis dan otak dapat dihambat. Sesuai yang disampaikan oleh (Potter \& Perry, 2006), panas juga merangsang serat saraf yang menutup gerbang sehingga transmisi implus nyeri ke medula spinalis dan otak dapat dihambat. Penurunan nyeri dengan transmisi yang dipengaruhi oleh teori gate control yaitu apabila terdapat impuls yang ditransmisikan oleh serabut berdiameter besar karena adanya stimulasi kulit, sentuhan, getaran, hangat dan dingin serta sentuhan halus, impuls ini akan menghambat impuls dari serabut berdiameter kecil di area SG (Substansia Gelatinosa) sehingga sensasi yang dibawa oleh serabut kecil akan berkurang atau bahkan tidak dihantarkan ke otak oleh SG, karenanya tubuh tidak dapat merasakan nyeri. Menurut Potter dan Perry, (2006), mekanisme terjadinya penurunan nyeri akibat dilakukan kompres hangat karena ketika panas diterima reseptor, impuls akan diteruskan menuju hipotalamus posterior akan terjadi reaksi reflek penghambatan 
simpatis yang akan membuat pembuluh darah berdilatasi sehingga membantu meningkatkan aliran darah ke bagian perut bawah yang mengalami nyeri/dismenorea, panas meredakan nyeri dengan menyingkirkan produk-produk imflamasi seperti bradikinin, histamin dan prostaglandin yang menimbulkan rasa nyeri lokal.

Oleh karena itu, bagi responden yang mengalami dismenorea primer sebaiknya dapat melakukan kompres air hangat sehingga nyeri pada saat dismenorea primer dapat teratasi dan tidak mengganggu aktifitas sehari-hari.

\section{Perbandingan Terapi Air Putih dan Kompres Hangat}

Hasil penelitian yang dilakukan di Pondok Pesantren Al-Hikmah Way Halim Bandar Lampung tentang terapi air putih dan kompres air hangat didapatkan hasil bahwa masing-masing terapi memiliki pengaruh dalam mengurangi skala nyeri haid (dismenorea primer). Namun berdasarkan nilai signifikansi nilai rata-rata nyeri setelah diberikan terapi, didapatkan hasil bahwa teknik kompres air hangat lebih efektif dibandingkan dengan terapi air putih. Nilai rata-rata skala nyeri haid sebelum diberikan terapi air putih 5,50 dan setelah diberikan terapi air putih mengalami penurunan menjadi 3,00. Sedangkan, nilai rata-rata skala nyeri haid sebelum diberikan kompres air hangat 4,69 dan setelah diberikan kompres air hangat menjadi 2,06. Kemudian pada hasil uji statistik menggunakan T-Test Independent didapatkan hasil rata-rata skala perbedaan sesudah kompres hangat>rata-rata perbedaan skala sesudah terapi air putih yaitu 2,625>2,500. Jadi artinya pada penelitian ini bahwa kompres air hangat lebih efektif dibandingkan dengan terapi air putih dalam penurunan skala nyeri haid pada siswa di Pondok Pesantren Way Halim Bandar Lampung.

Hasil penelitian ini didukung oleh teori yang menyebutkan bahwa penggunaan kompres hangat diharapkan dapat meningkatkan relaksasi otot-otot dan mengurangi nyeri akibat spasme atau kekakuan serta memberikan rasa hangat lokal. Pada umumnya panas cukup berguna untuk pengobatan. Panas meredakan iskemia dengan menurunkan kontraksi dan meningkatkan sirkulasi. Kompres hangat dapat menyebabkan pelepasan endorfin tubuh sehingga memblok transmisi stimulasi nyeri. Menurut teori gate-control kompres hangat dapat mengaktifkan (merangsang) serat-serat non-nosiseptif yang berdiameter besar ( A- $\alpha$ dan A- $\beta$ ) untuk 'menutup gerbang' bagi seratserat yang berdiameter kecil ( $\mathrm{A}-\delta$ dan $C$ ) yang berperan dalam menghantarkan nyeri, sehingga nyeri dapat dikurangi (Price \& Wilson, 2006). Upaya menutup pertahanan tersebut merupakan dasar terapi menghilangkan nyeri.

Menurut peneliti kesesuaian tersebut disebabkan oleh salah satu faktor yaitu, metode kompres air hangat merupakan salah satu metode non farmakologi dianggap sangat efektif dalam menurunkan kasus-kasus nyeri karena dengan memberikan kompres air hangat, dapat memenuhi kebutuhan rasa nyaman, megurangi atau membebaskan nyeri, mencegah terjadinya spasme otot, dan memberikan rasa hangat. Panas juga merangsang serat saraf yang menutup gerbang sehingga transmisi implus nyeri ke medulla spinalis dan otak dapat dihambat. Pada umumnya panas cukup berguna untuk pengobatan dan meningkatkan aliran darah kebagian yang cidera (Potter, 2005).

Oleh karena itu, bagi responden sebaiknya mampu mengaplikasikan berbagai metode pengobatan dismenorea. Dalam hal ini kompres air hangat terbukti sangat efektif untuk mengurangi nyeri saat menstruasi. Selain itu, metode ini mudah dilakukan sehingga dapat dilakukan oleh semua penderita dismenorea.

\section{KESIMPULAN}

Hasil penelitian menyimpulkan bahwa ada pengaruh telur rebus terhadap percepatan penyembuhan luka perineum pada ibu nifas $(p=0,000)$, dari 32 
responden menunjukan bahwa proporsi kesembuhan luka yang lebih cepat didominasi oleh responden pada kelompok perlakuan yaitu kelompok yang mengonsumsi telur rebus sebanyak 12 orang $(75 \%)$ yang sembuh kurang dari 7 hari.

Peneliti menyarankan kepada tenaga kesehatan BPM agar menganjurkan kepada ibu nifas yang mengalami luka perineum baik secara episisotomi maupun ruptur perineum untuk mengonsumsi telur rebus saat masa nifas untuk mempercepat penyembuhan luka perineum. Mahasiswa dapat melakuan penelitian lanjutan dalam memberikan asuhan kebidanan masa nifas terhadap percepatan penyembuhan luka perineum. Ibu nifas yang mengalami luka jahitan perineum untuk mengonsumsi telur rebus untuk memperbaiki sel-sel yang rusak agar luka perineum bisa lebih cepat sembuh sehingga dapat menghindarkan ibu dari bahaya infeksi masa nifas.

\section{DAFTAR PUSTAKA}

Anurogo, Wulandari. 2011. Cara Jitu Mengatasi Nyeri Haid. Yogyakarta: Andi Yogyakarta.

Baziad, Ali. 2008. Endokrinologi Ginekologi. Jakarta: Media, Aesculapius Fakultas Kedokteran Universitas Indonesia.
Karina Nurin R, Anzhor Adhi. 2017. Keajaiban Terapi Air Putih. Yogyakarta: HEALTHY.

Ni Made Sri Dwi Lestari. (2013). Pengaruh Dismenorea pada Remaja, Jurnal Seminar Nasional FMIPA UNDIKSHA, Jakarta.

Paulus, Pertiwi, Susmini (2017). Pengaruh Terapi Air Putih Terhadap Penurunan Dismenorhea Primer Pada Remaja Putri Kos Bambu Kelurahan Tlogomas Kota Malang. Jurnal Penelitian Universitas Tribhuwana Tunggadewi Malang, Malang.

Potter \& Perry. 2007. Buku Ajar Fundamental Keperawatan: Konsep, Proses, dan Praktik, edisi 4, Volume 2. Jakarta: EGC

Price, S. A. dan Wilson, L. M, 2006. Patofisiolog : Konsep Klinis Proses-Proses Penyakit, Edisi 6, Volume 1. Jakarta: EGC

Rakhma, Astrida. (2012). Gambaran Derajat Dismenore dan Upaya Penanganannya Pada Siswi Menengah Kejuruan Arjuna Depok Jawa Barat, Skripsi, Universitas Negeri Syarif Hidayatullah Jakarta, Jakarta.

Utami V.W, 2014, Hubungan pengetahuan tentang dismenorea dengan prilaku pencegahan pada remaja putri kelas $X$ dan XI di SMA Gajah Mada Bandar Lampung. Universitas Malahayati Bandar Lampung. 